\title{
ENFORCEMENT OF HONG KONG SAR COURT JUDGMENTS IN THE PEOPLE'S REPUBLIC OF CHINA
}

\author{
Kong Qingjiang*
}

\section{INTRODUCTION}

On 1 July 1997 Hong Kong entered a new era. It was transformed from a British colony into a Special Administrative Region (SAR) of the People's Republic of China (PRC). The far-reaching impact of the handover of Hong Kong is not to be easily overstated. Although, for the time being, the impact may lie more in political status than in institutions, it will in the long run certainly prove also in the sphere of institutions.

The judicial system has long been the heart of Hong Kong's legal order which plays an important role in maintaining the stability of Hong Kong. With this perception in mind, the Chinese government, whose long-term interest lies in the stability and prosperity of Hong Kong, committed itself, in both the Sino-British Joint Declaration ${ }^{1}$ and the Basic Law of Hong Kong Special Administrative Region (the Basic Law), ${ }^{2}$ to maintain that judicial system. It was even strengthened with the vesting of the power of final adjudication in the Hong Kong $\mathrm{SAR}^{3}$. Correspondingly, the enforcement of court decisions in Hong Kong should be secured.

It goes without saying that the enforcement of judgments is primarily a matter for the Hong Kong SAR courts themselves. There is, however, one important aspect which deserves specific attention: the enforcement of judgments

\footnotetext{
* Institute of Commerce, Hangzhou, China. I am indebted to Professor Ko SwAN SIK and Dr.PETER MACALISTER-SMITH for their invaluable comments on earlier versions of this article. I am also grateful for the editorial assistance provided by the Yearbook Editors.

' Part III of the Elaboration by the Government of the People's Republic of China of its Basic Policies regarding Hong Kong, constituting Annex I to the Sino-British Joint Declaration, states: "After the establishment of the Hong Kong Special Administrative Region, the judicial system previously practised in Hong Kong shall be maintained except for those changes consequent upon the vesting in the courts of the Hong Kong Special Administrative Region of the power of final adjudication".

${ }^{2}$ Art.81 para.2 of the Basic Law states: "The judicial system previously practised in Hong Kong shall be maintained except those changes consequent upon the establishment of the Court of Final Appeal".

${ }^{3}$ See n.2. Contrary to the situation before the handover, when the United Kingdom Privy Council served as Hong Kong's final appeal judicial organ, the judicial system in Hong Kong SAR will become an independent and separate system, with its own court of final appeal.
}

Asian Yearbook of International Law, Volume 7 (Ko Swan Sik et al., eds.

( Kluwer Law International; printed in the Netherlands), pp. 269-278 
of the Hong Kong SAR courts in the rest of the PRC (hereinafter referred to as 'mainland China' or 'the mainland'). Before the handover the question was relatively simple: Hong Kong being under British rule, the recognition and enforcement of Hong Kong judgments in China was treated by reference (canzao) as recognition and enforcement of foreign judgments ${ }^{4}$. After 30 June 1997, these judgments must in principle be deemed to be municipal judgments, but because of the system of autonomy under the 1984 Joint Declaration and the Basic Law, the Hong Kong SAR is to be considered a separate jurisdiction from the judicial point of view. Thus a number of questions arise: Are the judgments of Hong Kong SAR courts to be treated as foreign judgments if they are to be enforced on the mainland? In other words, will the judicial assistance rendered be classified as international assistance or domestic co-operation? Obviously, these questions are by no means of theoretical interest only. The present article will deal with this issue of enforcement of Hong Kong judgments in mainland China, in the field of civil and commercial cases.

\section{ECONOMIC IMPLICATIONS OF PROPER ENFORCEMENT OF HONG KONG JUDGMENTS}

In view of the economic links between Hong Kong and the mainland, the question of the enforcement of Hong Kong judgments should be looked at from the angle of the significance of Hong Kong's judicial system for the economic prosperity of Hong Kong. The more so since a proper enforcement of judgments forms the final and decisive part of a fair and effective judicial system.

Hong Kong's prosperity depends on its linkage with other economies, among which the mainland has a large share. The mainland is in fact the largest trading partner of the Hong Kong SAR. Conversely, the Hong Kong SAR has become the second largest trading partner of the mainland. Hong Kong is a major services centre for the mainland and particularly for the neighbouring province of Guangdong, prcviding such supporting infrastructural facilities as seaport and airport as well as institutional services like banking and insurance. Hong Kong is the most important source of external investment on the mainland, accounting for nearly three-fifth of the total external direct investment there. On the other hand, the mainland is the second largest source of inward direct investment in Hong Kong, accounting for 20 percent of the total ${ }^{5}$. Financial transactions between the Hong Kong SAR and the mainland have grown

\footnotetext{
4 The Chinese attitude towards the 'question of Hong Kong', was based on the 'unequal treaties' hypothesis. Hong Kong judgments, like anything else deriving from the 'unequal treaties', were not officially viewed as 'foreign'. Yet they were treated by reference to the factual, international, relationship.

${ }^{5}$ The figures can be obtained from the Internet web site of the Hong Kong SAR Government Information Centre.
} 
substantially over the past years. All of the four specialized national banks ${ }^{6}$ of the mainland as well as other banks have their presence in Hong Kong, with the Bank of China being the second largest bank there. Conversely, there is an increasing presence of Hong Kong banks in mainland China. Even more importantly, the Hong Kong SAR is used as a major funding centre by the mainland. ${ }^{7}$ In addition, it is common for multinational enterprises wishing to develop relations with mainland China to establish regional headquarters in Hong Kong. With the expanding economy of the mainland, it is to be expected that most Hong Kong-incorporated companies as well as Hong Kong-based subsidiaries of multinational enterprises will at some time develop closer links with the mainland.

In this regard, it is important to point out that Hong Kong's external economic relations and its judicial practice interact. Though more study is needed to define this linkage, it is plausible to make an argument that a fair and efficient judicial system is by nature commerce-friendly. On this assumption it is relevant to examine the importance of adequate enforcement of judgements of Hong Kong courts in mainland China for the external economic position of Hong Kong.

The existence of extensive external economic relations implies prospective disputes. Hong Kong has earned fame for its rule-based commercial environment and its fair and efficient judicial system, including efficient and equitable means of dispute settlement. In such a system the proper enforcement of judgments is indispensable and is, consequently, conducive to Hong Kong's economic prosperity.

The close economic links between Hong Kong and the mainland inevitably give rise to disputes between mainland-based and Hong Kong-based parties, irrespective of whether the latter is a company incorporated in Hong Kong or a Hong Kong subsidiary of a foreign company. The Hong Kong SAR courts may have jurisdiction over such disputes in accordance the recognized principles of territorial or personal jurisdiction. Moreover, the parties to a business transaction may have chosen the court of the venue of the transaction as the competent court and the law of that venue as the applicable law for prospective disputes. Accordingly many prospective and fait accompli disputes are referred to the Hong Kong courts because of the good reputation of these courts. This practice is heightened by the fact that the laws of Hong Kong are more developed and predictable than the laws of the mainland.

Against this backdrop, there will be cases which have been adjudicated by Hong Kong courts and of which the resulting judgments have to be enforced in

\footnotetext{
${ }^{6}$ They are Bank of China, the Industrial and Commercial Bank of China, the Agriculture Bank of China and the China Construction Bank.

${ }^{7}$ Most of the fund-raising activities in the territory are related to syndicated loans. Since mid1993, an increasing number of the largest state-owned enterprises of the mainland have $\mathrm{H}$-shares listed at the Hong Kong Stock Exchange.
} 
mainland China because the person or property subject to the enforcement is or is located on the mainland. An inadequate regulation of this matter would not only give rise to individual injustice, but would impair a proper execution of the judicial decision and thus be detrimental to the reputation of the Hong Kong judicial system, which would, in its turn harm Hong Kong's status as an international economic centre.

\section{ENFORCEMENT OF JUDGMENTS IN THE PRC}

How are municipal and foreign judgments enforced in the PRC ${ }^{8}$

\subsection{Enforcement of municipal judgements}

According to Article 207 of the current Civil Procedure Law (CPL) of the PRC, a final judgment is enforced by the court ('People's Court') ${ }^{9}$ that has entertained the case in first instance ('diyi sheng fa yuan') ${ }^{10}$. This rule applies irrespective of whether the final and legally effective judgment was rendered by that court or, in appeal, by a higher court. Although it is correct to hold that the court in question has competence to enforce the judgment even outside its jurisdiction, pursuant to Article 210 of the CPL the enforcement may be delegated to the court of another locality in case the subject of the enforcement is in that other place. It is within the discretion of the first instance court to opt for executing the enforcement itself or delegating it to another court. ${ }^{11}$ In the latter case, the delegated court is under an obligation to enforce the award without examining or reviewing the judgment concerned. Yet, in practice the original court seems to prefer to enforce its own decisions, even where the subject of

\footnotetext{
${ }^{8}$ According to the Civil Procedure Law (CPL) of the PRC, there are two types of judicial awards: judgments (panjue) and decisions (caijue). However, the distinction makes no difference to their enforcement. In the present article, no distinction is made for the sake of convenience.

${ }^{9}$ See, for a brief survey of the Chinese judicial system, Li Shuangyuan and Lü Guoming, "The law of international civil procedure in China", 6 AsYIL (1996) 135 at 137.

${ }^{10}$ CPL Art.207 para.1.

${ }^{11}$ CPL Art.210 reads: "If the person against whom [a judicial award] is to be enforced or the property, which is the subject of enforcement, is located at another place [outside the court's jurisdiction], the enforcement may be delegated to the local court [of that other place]. The delegated court shall, within fifteen days of the receipt of the letter of delegation, start enforcement, and shall not refuse to do so. After the enforcement is completed, the delegated court shall notify the delegating court in written form about the result of the enforcement In case the enforcement is not completed within thirty days, the notification shall contain the particulars of the enforcement". "If the delegated court fails to execute the enforcement within fifteen days of the receipt of the letter of delegation, the delegating court may request the court superior to the delegated court to direct the delegated court to enforce the judicial award."
} 
enforcement is located outside its jurisdiction, primarily in order to keep the authority inherent in the enforcement in its own hands. ${ }^{12} 13$

\subsection{Enforcement of foreign judgments in the PRC}

According to Article 267 of the Civil Procedure Law ${ }^{14}$, where a legally effective judgment rendered by a court of a foreign country needs to be recognized and enforced by the a court of the PRC, the interested party may directly apply for recognition and enforcement to the Intermediate People's Court (zhongji renmin fayuan $)^{15}$ which has jurisdiction. A similar request may also be made by the foreign court, ${ }^{16}$ in accordance with relevant international treaties or by virtue of reciprocity ${ }^{17}$.

The enforcement of foreign judgments differs from enforcement of municipal ones on the basis of delegation in four respects: First, it is based, apart from reciprocity, on an existing treaty binding the PRC and the foreign country involved, while the enforcement of a judgment of another municipal court is an obligation of the delegated court without any precondition; secondly, whereas

${ }^{12}$ In dealing with cases involving parties from other jurisdictions, the local court is often seen biased in favour of the local parties, either driven by the interests of, or under the pressure from, the locality.

${ }^{13}$ It should be borne in mind that enforcement of judgments is among the most controversial issues of the judicial system of the mainland today. The people's courts are not always able to enforce their judgments in civil and commercial cases. China being a country where the administrative power has traditionally dominated the political and social affairs of the country, the rule of law is more a function of the political environment and the interests of the political leadership in having the law either or not properly implemented than a logical consequence of the legal norms. Thus, it is not uncommon for enforcement of court decisions to be obstructed by interference from influential authorities and to have to rely on the prestige and authority of the judges concerned, so as not to become the victim of bias and remain ineffective. Consequently, the people's courts do not enjoy the same high status as their counterparts in Hong Kong.

${ }^{14}$ Art 267 reads: "If a legally effective judgment or decision by a foreign court requires recognition and enforcement by a people's court of the People's Republic of China, the party concerned may directly apply for recognition and enforcement to the competent Intermediate People's Court. The foreign court may also, in accordance with the provisions of the international treaties concluded or acceded to by that foreign country and the People's Republic of China, or with the principle of reciprocity, request recognition and enforcement by a people's court".

${ }^{15}$ See loc.cit.n.9.

${ }^{16}$ Ibid. at 163 .

${ }^{17}$ Cf. loc.cit.n.9 at 163. As to which Intermediate People's Court has jurisdiction, reference is here made to Arts.22 and 243 of the Civil Procedure Law. Art.22 determines that the people's court of the place where the defendant has his domicile is competent. Article 243 further provides that, where the defendant has no domicile in the PRC, the competent court is the people's court within whose jurisdiction the contract was signed or performed, or the object of the lawsuit is located, or the defendant's distrainable property is located, or the torts have been committed, or the defendant's representative office is located. 
review is not allowed in case of delegated enforcement of municipal judgments, review of the foreign judgment on its merits is the general rule; thirdly, enforcement of foreign judgments falls exclusively within the jurisdiction of Intermediate People's Courts ${ }^{18}$; fourthly, in the case of foreign judgments the interested party or the foreign court initiates the enforcement, while the delegated enforcement of a municipal judgement does not need the involvement of an interested party.

Article 268 of the Civil Procedure Law sets forth the requirements to be fulfilled by a foreign judgment in order to be eligible for recognition and enforcement in the PRC: (1) the judgment must be final and legally effective; (2) the judgment is in compliance with the basic principles of the law of the PRC and not detrimental to its sovereignty, security and social and common goods. ${ }^{19}$ The provision mandates the people's court to review the judgment of the foreign court on compatibility with the relevant international treaties to which the PRC is a party, or, in the absence of such a treaty, with the principle of reciprocity, with a view to ensure that the above requirements are fulfilled. No recognition shall be accorded to, nor shall enforcement take place of, judgments that are considered to be contradictory to the basic principles of the law of the PRC or detrimental to its sovereignty, security, social and common goods. $^{20}$

\section{THE LEGAL STRUCTURE OF THE RELATIONSHIP BETWEEN THE HONG KONG SAR COURTS AND THOSE OF THE MAINLAND UNDER THE BASIC LAW}

In the Elaboration by the Government of the People's Republic of China of its Basic Policies regarding Hong Kong, attached to the Sino-British Joint Dec-

\footnotetext{
${ }^{18}$ The court system of the PRC may be illustrated as follows: The Supreme People's Court (SPC) is the court of final appeal although it also adjudicates certain categories of cases falling under its direct jurisdiction. Under the SPC there are 31 Higher People's Courts (HPC) at the provincial level; under each HPC there are a number of Intermediate People's Courts (IPC); finally, under each IPC there are the Basic-level People's Courts (BPC) the number of which is normally in line with the administrative zoning of the country.

${ }^{19}$ Art 268 reads: "In the case of an application or request for recognition and enforcement of a legally effective judgment or decision of a foreign court, the people's court shall, after examining it in accordance with the international treaties concluded or acceded to by the People's Republic of China or with the principle or reciprocity, and arriving at the conclusion that it does not contradict the basic principles of the law of the People's Republic of China nor violates the sovereignty, security and social and common goods of the country, recognize the validity of the judgment or written order, and, where it [the judgment or decision] is to be enforced, issue a writ of enforcement in accordance with the relevant provisions of this Law ...".

${ }^{20}$ It should be noted that Art. 268 treats recognition differently from enforcement. In the event of recognition of foreign judgments no writ is needed; in the event of enforcement the people's court is to issue a writ of enforcement.
} 
laration as its Annex I, the Chinese government committed itself to assist or authorize the Hong Kong SAR Government to make appropriate arrangement for reciprocal judicial assistance with foreign states. ${ }^{21}$ Understandably, it does not refer to judicial assistance between Hong Kong SAR and mainland China. The Basic Law of Hong Kong, though, contains a vaguely worded stipulation in this regard. Article 95 states: "The Hong Kong Special Administrative Region, may, through consultations and in accordance with law, maintain juridical relations with the judicial organs of other parts of the country, and they may render each other assistance". The provision leaves much to be clarified.

First, it fails to provide an answer to the question whether the Hong Kong courts may enforce their final judgments on the mainland by themselves. Since the Basic Law clearly stipulates that as a rule no law of mainland China will apply to Hong Kong, ${ }^{22}$ the provision of the Civil Procedure Law on the enforcement of judgments of municipal courts may also not qualify to be invoked for judgments of Hong Kong courts. On the other hand, unless an arrangement is made to the effect that the mainland courts can reciprocally enforce their judgments in Hong Kong SAR themselves, it seems not likely that the Hong Kong SAR courts will be given such authorization. In fact, such a reciprocal arrangement appears not quite desirable for the Hong Kong SAR.

Secondly, the provision is not clear on the issue whether the Hong Kong SAR courts are to deal through consultation with the courts on the mainland individually for assistance on a case-by-case basis. Given the thousands of courts at various levels across the mainland ${ }^{23}$, this would be a great burden on the part of the Hong Kong courts and, in view of the politicized atmosphere referred to earlier, would not hold any assurance for an adequate enforcement.

Thirdly, the provision fails to elaborate on the law which would govern the arrangement to be made between the Hong Kong SAR courts and those on the mainland.

Lastly, the provision fails to specify whether the mainland people's courts are to review the Hong Kong judgments before recognizing and enforcing them.

\section{A PROPOSAL FOR AN AGREEMENT TO FACILITATE THE ENFORCEMENT OF HONG KONG SAR JUDGMENTS IN MAINLAND CHINA}

It should be made clear from the outset that the absence of an arrangement as envisaged earlier does not mean that a Hong Kong judgment cannot be enforced on the mainland. The practice of such enforcement before and after the

\footnotetext{
${ }^{21}$ Elaboration, Part III para.7.

${ }^{22}$ Except those referred to in the Basic Law, see Art.18 Basic Law.

${ }^{23}$ See n. 18.
} 
handover so far serves as an example. The working relationship that has developed on a case-by-case basis between the Hong Kong and mainland courts has been the only basis for the Hong Kong courts to have their judgments enforced on the mainland. The requested people's court would recognize and enforce the Hong Kong judgment after reviewing it and having concluded that it does not contravene the basic principles of the law of the PRC and is not detrimental to the sovereignty, security and social and common goods of the PRC. It is not difficult to see that the Hong Kong judgments have been treated as foreign judgments.

The advantages of a more explicit arrangement are obvious:

(1) An appropriate arrangement would oblige the mainland people's courts to respect the judicial process of the Hong Kong SAR courts and to honour the Hong Kong SAR judgments, thus limiting the possibility of the people's courts to review the Hong Kong judgments on their merits and avoiding a retrial of the case.

(2) An arrangement would ensure a simpler and a more expeditious procedure of enforcement, e.g. by prescribing direct enforcement of a Hongkong SAR judgment by the competent mainland court, making a review of the judgment and an execution order, required in the case of the enforcement of a foreign judgment, redundant.

(3) An explicit arrangement would to a large extent reduce, if not eradicate, the possibility of manipulation of the enforcement of the judgments by local courts on the mainland. ${ }^{24}$

It is no easy task to formulate such an arrangement. Since, understandably, from a Chinese perspective matters relating to Hong Kong are domestic affairs, a 'treaty' on mutual judicial assistance between the Central People's Government and the Hong Kong SAR Government is not feasible. Nevertheless, some kind of joint arrangement appears desirable: First, it is in the interest of the mainland and in accordance with its commitments not to be a mere silent partner of the Hong Kong SAR, nor a paternalistic superior, but a genuine partner. Secondly, it is up to the Central People's Government to safeguard the autonomy of the Hong Kong SAR, including its independent judicial system. More specifically, the Central Government is under an implicit obligation to ensure that Hong Kong SAR judgments be enforced without alteration, not only in foreign countries, but also in the other jurisdictions of the PRC. It could be argued that, unless the Standing Committee of the National People's Congress (NPC) provides an adequate and elaborative interpretation of Article 95 of the Basic $\mathrm{Law}^{25}$, other ways must be found to achieve the desired goal.

\footnotetext{
${ }^{24}$ See CPL Art. 268.

${ }^{25}$ It should be noted that, according to Art.158 of the Basic Law, the power of interpretation of that Law is vested in the Standing Committee of the National People's Congress. The Hong Kong SAR courts are authorized, for the purpose of 'adjudicating cases', to interpret the provisions of the Basic Law "which are within the limits of the authority of the [Hong Kong SA] Region". It is not clear whether the enforcement of judgements falls within the scope of 'adju-
} 
One alternative is to continue the present working relationship between the courts of Hong Kong and those of mainland China on a case-by-case basis without any underlying legal framework.

A second alternative is to have an agreement between the two sides on the specific issue of enforcement of Hong Kong SAR judgments on the mainland. The Supreme People's Court (SPC) and the Department of Justice of the Hong Kong SAR Government would agree on an informal joint memorandum under which an order of enforcement must be obtained from a Higher People's Court enabling (and directing?) the Intermediate People's Court to carry out the enforcement of a judgment of the Hong Kong court. Under such an arrangement, the Higher People's Court would be designated as the authority responsible for accepting delegation for enforcement of final judgments of the Hong Kong courts.

Under a third alternative the Supreme People's Court and the Hong Kong Department of Justice would issue complementary internal directives on the enforcement of each other's judgments. ${ }^{26}$

With respect to the first alternative, it should be borne in mind that a working relationship, regardless of however well elaborated and organized, will always be subject to arbitrary unilateral suspension, and the judgments of Hong Kong courts would be prone to manipulative treatment by the mainland courts. Therefore, a de facto working relationship between the two sides seems inadequate to ensure the adequate enforcement of Hong Kong SAR judgments in mainland China.

The second alternative is a more formal mode of co-operation. It requires some co-ordination between the two sides in respect of public policy, e.g., sovereignty, security and social and common goods. It is expected to be a slow and inefficient procedure, involving additional expenses for the parties concerned and, consequently, not suitable to Hong Kong's business-friendly environment.

dicating cases'. As a matter of fact, the provision leaves room for a potential constitutional crisis. A good example was provided by the recent case before the Court of Final Appeal concerning the right of abode of persons of Chinese nationality born outside Hongkong of parents who are Hong Kong SAR permanent residents. See, on the case, the Hong Kong Government Press Releases on www.info.gov.hk/jud.

${ }^{26}$ In the Chinese set-up the Ministry of Justice is responsible for the negotiation of judicial assistance agreements with foreign countries, but has no power to issue binding orders for the courts. It is up to the Supreme People's Court to issue such orders.

${ }^{27}$ On 30 March 1999 the Arrangement regarding Mutual Requests for Assistance in the Service of Judicial Documents between the Mainland and Hong Kong SAR was simultaneously promulgated by the Supreme People's Court (SPC) of the PRC and the High Court of Hong Kong. It covers only the mutual assistance in service of judidical documents between the courts of the Hong Kong SAR and the mainland, leaving open the mutual assistance in enforcement of judgments. Further negotiations are reportedly being held for the purpose of mutual assistance in the field of the enforcement of judgments. The Arrangement is by its nature an agreement between the SPC and the High Court of Hong Kong. However, in the accompanying explanatory speech 
The third alternative seems to be the most favourable one. An arrangement along these lines would have the same effect as the second alternative, while being more efficient. It could be made even more attractive by proscribing the requested and enforcing court not to review the other side's judgment.

by a Vice President of the SPC it was referred to as an internal directive. The Arrangement is similar to the approaches embodied in the second and third suggested alternatives in this article. 